JAOS

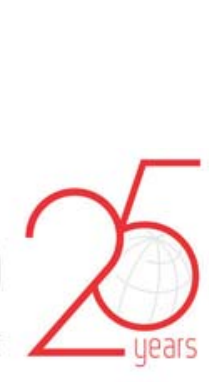

\title{
Factors affecting the periapical healing process of endodontically treated teeth
}

\section{Abstract}

Roberto HOLLAND ${ }^{1}$

João Eduardo GOMES FILHO'

Luciano Tavares Angelo CINTRA ${ }^{1}$

Índia Olinta de Azevedo QUEIROZ1

Carlos ESTRELA ${ }^{2}$
Submitted: September 2, 2016 Modified: February 8, 2017

Accepted: March 11, 2017

Corresponding address: João Eduardo Gomes Filho

Departamento de Odontologia Restauradora. Faculdade de Odontologia de Araçatuba. Univ. Estadual Paulista R. José Bonifácio, 1193 - Vila Mendonça - 16015-050 Araçatuba - SP - Brazil. Phone: (+55) 1836363252 - Fax: (+55) 1836363253 e-mail: joao@foa.unesp.br
Tissue repair is an essential process that reestablishes tissue integrity and regular function. Nevertheless, different therapeutic factors and clinical conditions may interfere in this process of periapical healing. This review aims to discuss the important therapeutic factors associated with the clinical protocol used during root canal treatment and to highlight the systemic conditions associated with the periapical healing process of endodontically treated teeth. The antibacterial strategies indicated in the conventional treatment of an inflamed and infected pulp and the modulation of the host's immune response may assist in tissue repair, if wound healing has been hindered by infection. Systemic conditions, such as diabetes mellitus and hypertension, can also inhibit wound healing. The success of root canal treatment is affected by the correct choice of clinical protocol. These factors are dependent on the sanitization process (instrumentation, irrigant solution, irrigating strategies, and intracanal dressing), the apical limit of the root canal preparation and obturation, and the quality of the sealer. The challenges affecting the healing process of endodontically treated teeth include control of the inflammation of pulp or infectious processes and simultaneous neutralization of unpredictable provocations to the periapical tissue. Along with these factors, one must understand the local and general clinical conditions (systemic health of the patient) that affect the outcome of root canal treatment prediction.

Keywords: Root canal therapy. Periapical periodontitis. Endodontics. Clinical protocols.
'Universidade Estadual Paulista, Faculdade de Odontologia de Araçatuba, Departamento de Odontologia Restauradora, Araçatuba, SP, Brasil.

2Universidade Federal de Goiás, Faculdade de Odontologia, Departamento de Ciências

Estomatológicas, Goiânia, GO, Brasil. 


\section{Introduction}

The process of healing depends on the structural and functional replacement of the areas affected by intrinsic or extrinsic factors. It can involve the repair and regeneration of the affected site ${ }^{18}$. Additionally, inflammation is a defense mechanism that occurs in vascularized tissue. Connective tissue involves a process of repair via the formation of granulation tissue, whereas non-connective tissue, such as that of the glandular organs, smooth muscles, skeletal muscles and peripheral nerves, involves the proliferation, and therefore, regeneration, of the remaining tissue ${ }^{18}$. These two processes are dependent upon the regenerative capacity of the affected cells, the extent of the affected site, and the proliferative activity of the stromal tissue. Regeneration involves a process of tissue renewal with cells that have similar characteristics to those that were previously lost; it is the morphological and functional restoration of tissue. Conversely, repair is characterized by the formation of connective tissue at the site of the lesion, and the infiltration of fibroblast. The process of healing begins with inflammation, and is resolved by the clearance of the immunogen that induces the tissue response ${ }^{10}$.

Complete repair only occurs once the antigen has been neutralized during the inflammatory response. During pulp infection, the occluded blood supply of the root canal becomes conducive to bacterial proliferation. Furthermore, inflammation within the periapical region is elicited to neutralize the antigen. Bone resorption is also stimulated by this inflammatory response, and space is created for the infiltration of immune cells, which are then organized into a barrier to sequester the infection.

Bone resorption and bone formation are processes involving the activity of osteoclasts, osteoblasts, and osteocytes; they are affected by the systemic and local conditions ${ }^{66}$. However, bone homeostasis is disrupted during apical periodontitis, which promotes increased rates of bone resorption.

Ideally, cases of apical periodontitis should be characterized by a repair process that is asymptomatic in nature, an absence of radiographic abnormalities in the periradicular tissues, and evidence of biological sealing (cement sealing the foramina), or by the presence of a fibrous capsule with the infiltration of few inflammatory cells ${ }^{54}$. Thus, the application of clinical protocols should consider the local and systemic conditions that contribute towards the healing process.

This review aims to discuss the important therapeutic factors underlying the clinical protocols used during a root canal treatment. Additionally, we will analyze local and systemic conditions associated with the periapical healing process of endodontically treated teeth.

\section{Therapeutic factors that affect the repair process}

Biochemical preparation

Root canal shaping is an important step in endodontic therapy to achieve the apical healing and the cleaning and modeling of the root canal system. However, the complex root canal anatomy, associated with the presence of curvatures and ramifications, the shape, and the position of the apical foramina, can interfere and hinder the root canal shaping and cleaning ${ }^{79}$.

The advances in endodontic therapy, specifically in the development of new instruments made of nickeltitanium ( $\mathrm{NiTi}$ ) alloys (rotatory and reciprocating files) - with characteristics such as superelasticity (flexibility) and shape memory -, simplified the cleaning and shaping of root canals by reducing the instrumentation time and by keeping the original canal shape $5,35,88$. Besides, reduction of the occurrence of zips, ledges, perforations, and transporting of the root canals, especially in narrow and curved canals ${ }^{35,88}$, were also observed after using those instruments. Despite all these improvements, the possibility of fracture of NiTi instruments, mainly in root canals with severe curvatures, has been found ${ }^{76,82}$. Moreover, Panitvisai, et al. ${ }^{75}$ (2010) showed no reduction on the prognostic of endodontic treatment when a fractured instrument fragment is left within a root.

Investigations comparing the manual, rotary, and reciprocating systems and the association between them have been extensively performed $5,35,88$. Azar, et al. ${ }^{4}$ (2012) reported no significant differences in cleaning efficiency between manual and rotary instruments. Besides, evaluation of the apical bacterial extrusion promoted by reciprocating and rotary instrumentation showed that both systems extruded bacteria beyond the foramen; nevertheless, the reciprocating showed lesser extrusion than the rotary system ${ }^{107}$. Additionally, no differences in the efficacy of rotary and reciprocating systems for removing root filling material was identified ${ }^{93}$. However, both 
systems in association were able to remove a large amount of root filling material in the retreatment of curved canals ${ }^{84}$.

Subramaniam, et al. ${ }^{97}$ (2013) showed that both manual and rotatory instrumentation were able to reduce the aerobic and anaerobic microflora of root canals of primary molars. Meanwhile, bacteria were detected in root canals of teeth with apical periodontitis before and after the use of hand and rotary $\mathrm{NiTi}$ instrumentation and no difference in bacterial reduction in infected canals after using both instruments was observed ${ }^{83}$. Furthermore, Pinheiro, et al. ${ }^{80}$ (2012) compared the cleaning effectiveness of manual, hybrid, and rotary instrumentation to remove Enterococcus faecalis from primary molar teeth. The authors found that all techniques were able to reduce the number of Enterococcus faecalis; thus, hybrid instrumentation showed to better reduction when compared with manual.

Therewith, even with the improvement on the biomechanical preparation of root canal system using $\mathrm{NiTi}$ instruments, bacteria can survive and grow inside root canal systems or on apical biofilm47,83,105, compromising the periapical tissue repair. Therefore, the complete repair depends on the association of an effective irrigating solution, intracanal dressing, and root canal filling to the mechanical preparation.

\section{I rrigating solutions}

Root canal treatment (RCT) requires the use of irrigating solutions to provide an antimicrobial effect, remove debris, and neutralize the presence of organic compounds. Because of the risk of periapical extrusion via the apical foramen, irrigating solutions should be biocompatible and non-irritating to the periapical tissue $37,58,94$

The persistence of bacterial infection following root canal preparation reveals the limitations of the irrigating solutions, such as sodium hypochlorite $(\mathrm{NaOCl})$ and chlorhexidine ( $\mathrm{CHX})$. These solutions can only reduce the microbial population and, therefore, cannot entirely eliminate it. The sanitization process consists of the disinfection and enlargement of the root canal via the action of sodium hypochlorite and the instrumentation techniques of the root canal, respectively. Furthermore, these protocols reduce the remaining microbiota, which improves the efficacy of the intracanal dressing and increases the success rate of the endodontic treatment ${ }^{22}$

The efficacy of $\mathrm{NaOCl}$ and $\mathrm{CHX}$ on the incidence of Enterococcus faecalis infection was discussed in a systematic review and meta-analysis ${ }^{23}$. Sodium hypochlorite is a commonly used endodontic irrigant because of its antibacterial properties and its ability to dissolve organic tissue $21,50,103$.

The antibacterial action of $\mathrm{NaOCl}$ can be verified based on its physicochemical properties and its reaction with organic tissue ${ }^{21,50}$. Sodium hypochlorite acts as a solvent for organic compounds and lipids; it degrades fatty acids into the products of fatty acid salts (soap) and glycerol (alcohol), in a saponification reaction. This reduces the surface tension of the remaining solution. Furthermore, $\mathrm{NaOCl}$ is able to cause amino acids to undergo a neutralization reaction to form water and salt. Similarly, hypochlorous acid $(\mathrm{HOCl})$ acts as solvent in the presence of organic tissue, and releases chlorine; this combines with the amine group of the protein and forms chloramines, in a chlorination reaction. Hypochlorous acid and hypochlorite can undergo a reaction with amino acids, which would result in their degradation and hydrolysis. The chlorination reaction between chlorine and the amine group $\left(-\mathrm{NH}_{2}\right)$ results in the product of chloramines, which interfere with cell metabolism. Chlorine is a strong oxidant; it has antimicrobial properties, and is able to inhibit bacterial enzymes. This results in the irreversible oxidation of sulfhydryl (-SH) group, which is essential for the function of bacterial enzymes ${ }^{21,50}$.

Frough-Reyhani, et al. ${ }^{26}$ (2016) evaluated the antimicrobial activity of $1 \%, 2.5 \%$, and $5 \% \mathrm{NaOC}$ solution in the treatment of Enterococcus faecalis biofilms at different stages of development and showed that $2.5 \%$ and $5 \% \mathrm{NaOCl}$ completely eliminated the biofilms in three stages of development, whereas the bacteria in mature and old biofilms were more resistant to $1 \% \mathrm{NaOCl}$. In an in vitro study, Siqueira, et al. ${ }^{95}$ (2000) found no difference in the efficacy of the antibacterial activity of $1 \%, 2.5 \%$, and $5 \% \mathrm{NaOCl}$ solution. Moreover, regardless of the concentration, $\mathrm{NaOCl}$ was also ineffective in the removal of the smear layer formed during root canal preparation; the smear layer impairs the cleaning of the root canal system ${ }^{59}$. Reinfection of the root canal system after instrumentation has been reported ${ }^{83}$. Teeth with periapical lesions and a higher concentration of endotoxins have also been detected ${ }^{36}$. Sodium hypochlorite solutions can inhibit the action of certain endotoxins; however, it is not effective against all of 
them $^{74}$

The smear layer is the material that is attached to the canal walls during root canal preparation. It is composed of dentin, remnants of pulp tissue (organic and inorganic components), chemical residues, and microorganisms. The use of EDTA and $\mathrm{NaOCl}$ solutions has been shown to be more effective to remove the smear layer ${ }^{104}$

Nery, et al. ${ }^{73}$ (2011) reported similar results following the use of $1 \%$ and $2.5 \% \mathrm{NaOCl}$ solution during the endodontic irrigation of canine teeth. The incidence of pulp necrosis and apical periodontitis was reported and treated in one session. Therefore, the use of $1 \%$ and $2.5 \% \mathrm{NaOCl}$ solution had similar treatment efficacy. Nonetheless, the use of $2.5 \% \mathrm{NaOCl}$ solution is preferred for clinical purposes because of its more stable nature.

Recently, new antimicrobial approaches to disinfection of root canals have been proposed, such as photodynamic therapy (PDT), a therapy that combines the association between a photosensitizer dye and a specific wavelength light Laser (light amplification by stimulated emission of radiation) or Led (light emitting diode). The singlet oxygen, which is responsible for the disruption of the bacterial membrane and inactivation of endotoxins, promotes antimicrobial action ${ }^{67,92}$ Several investigations have been reporting that PDT reduces the number of bacteria from root canal ${ }^{30,61,108}$ and shows the same efficacy of $2.5 \%$ and $5 \% \mathrm{NaOCl}$ solution to eliminate Enterococcus faecalis ${ }^{114,115}$ In addition, Vaziri, et al. ${ }^{110}$ (2012) found that the combination of PDT and $2.5 \% \mathrm{NaOCl}$ solution was more effective against Enterococcus faecalis. Moreover, Borsatto, et al. ${ }^{7}$ (2016) evaluated the response of the apical and periapical tissues of canine teeth with apical periodontitis after one session with and without antimicrobial photodynamic therapy (aPDT) and compared it with two sessions using calcium hydroxide as intracanal dressing. They showed that the better repair and small periapical lesions were associated with the two sessions using calcium hydroxide.

Thus, despite all of these new antimicrobial methods, $\mathrm{NaOCl}$ solutions are still the greatest choice for clinical procedure due to their effective antimicrobial potential. Moreover, because of the instability of these solutions, especially during storage and transportation time, the $1 \% \mathrm{NaOCl}$ solution may not be effective; thus, the $2.5 \% \mathrm{NaOCl}$ solution is the most recommended.

\section{Intracanal dressing}

Several types of medication have been developed and used as intracanal dressing ${ }^{51}$. However, the efficacy of some treatments has been questioned; this has contributed towards the increasing preference among professionals to perform RCT in a single session $34,68,77,81$. Additionally, the practice of singleappointment endodontics, as opposed to multipleappointment endodontics, has been encouraged by the negligible differences in the treatment outcomes between the two, which include an absence of postoperative pain and the clinical and radiographic repair ${ }^{77,78}$ of teeth. Conversely, studies assessing canine teeth have reported superior results with the practice of multiple-appointment endodontic treatment ${ }^{54,64}$

In an attempt to further clarify this issue, Holland, et al. ${ }^{54}$ (2003) conducted a study using canine teeth as a model. These specimens were characterized by a necrotic pulp and had periapical lesions that were treated in either one or two appointments. The teeth that were treated in two appointments received a course of calcium hydroxide intracanal dressing for 7 or 14 days. The root canals were filled with Sealapex and were evaluated for six months after the treatment. The authors observed that the use of calcium hydroxide for 7 or 14 days obtained better results than the singleappointment endodontic treatment. Furthermore, they attributed the repair process observed after the single appointment to the alkaline $\mathrm{pH}$ of Sealapex; once the root canals were filled with Sealapex, it showed better results than the other sealers that were used in teeth with apical periodontitis ${ }^{63,64}$

Georgopoulou, et al. ${ }^{33}$ (1993) reported that the calcium hydroxide intracanal dressing was more effective against anaerobic bacteria than the use of camphorated paramonochlorophenol. The high $\mathrm{pH}$ of calcium hydroxide, due to the release of hydroxide ions, is capable of altering the structural integrity of the cytoplasmic membrane of bacteria24. Additionally, the calcium hydroxide had an indirect effect on the anaerobic microorganisms of the root canal because of the reaction between calcium ion and aqueous carbon dioxide ${ }^{24}$. Calcium hydroxide also results in the degradation of bacterial lipopolysaccharides ${ }^{1,24}$.

The biological and antimicrobial action of calcium hydroxide is based on its dissociation into calcium and hydroxide ions, and on the action of these ions on tissues and bacteria ${ }^{24}$. Calcium hydroxide induces the deposition of a hard tissue bridge on the pulpal and 
periodontal connective tissue $\mathrm{e}^{54}$. Its action on connective tissue (pulpal and periodontal tissues) stimulates mineralization from the significant involvement of alkaline phosphatase and fibronectin ${ }^{54,71}$.

Nair, et al. ${ }^{72}$ (2005) evaluated the intracanal microbial status of the mandibular first molars with primary apical periodontitis, in humans, following single-appointment endodontic treatment. The results showed the anatomical complexity of the root canal system of the mandibular first molar, and highlighted the ineffectiveness of contemporary instruments and irrigation processes in the removal of local flora after only one appointment. This was mostly attributable to their organization as biofilms in inaccessible areas of the canal system. Therefore, to achieve a highly favorable long-term prognosis of the RCT, the stringent application of all nonantibiotic and chemomechanical measures must be taken to treat teeth with infected and necrotic root canals; additionally, these measures are required to disrupt the formation of biofilms and to minimize the intraradicular microbial load.

The challenges affecting a successful root canal preparation include the following factors: complex anatomy; number of canals; curvatures; root canal ramifications; shape; and position of apical foramina, which complicates cleaning 22,79 . Therewith, to achieve a complete root canal cleaning, an intracanal dressing must be used. Thus, the biological properties of calcium hydroxide, as well as its antimicrobial capacity to induce the deposition of a hard tissue, promoting a better repair, make it the intracanal medication recommended during the RCT.

\section{Root canal filling}

The goal of root canal obturation is to obtain complete sealing in order to hinder the communication between the root canal and the periapical tissue. This favors the process of apical and periapical repair after endodontic therapy ${ }^{53}$.

An ideal root canal sealer must have adequate physical, chemical, and biological properties ${ }^{31,86}$. Several factors can affect the success of RCT, including the type and composition of sealer utilized ${ }^{31,57,86}$. The presence and release of substances from the sealers can cause different reactions when in contact with tissue $^{86}$.

The reaction between calcium oxide and tissue fluid was previously described ${ }^{55}$. This reaction produces calcium hydroxide, which dissociates into calcium and hydroxide ions in the presence of water. Calcium ions then react with aqueous carbon dioxide within the tissue to form crystals of calcium carbonate, which subsequently stimulate the deposition of hard tissue (Figure 1). Therefore, root canal sealers that contain calcium hydroxide or calcium oxide have been clinically used.

The tissue response to Sealapex, CPM Sealer, and MTA Fillapex, which contain in their composition calcium hydroxide or calcium oxide, were evaluated in the subcutaneous tissue of rats. The results showed that all sealers induced a moderate inflammatory response at 7 and 15 days, which resolved over time. In addition, all sealers were capable of stimulating the deposition of mineralized tissue ${ }^{42,44}$. Another study ${ }^{43}$ evaluated the efficacy of RCT using the aforementioned sealers, in canine teeth, following a single session of endodontic treatment. Incomplete periapical tissue repair was reported, and the sealers were capable of controlling the root canal infection regardless of the differences in their antimicrobial activity ${ }^{20,101}$. The use of Sealapex and MTA Fillapex resulted in a similar seal and had a better response than the use of CPM Sealer. This was probably due to the fact that both sealers produced less of an inflammatory reaction, therefore

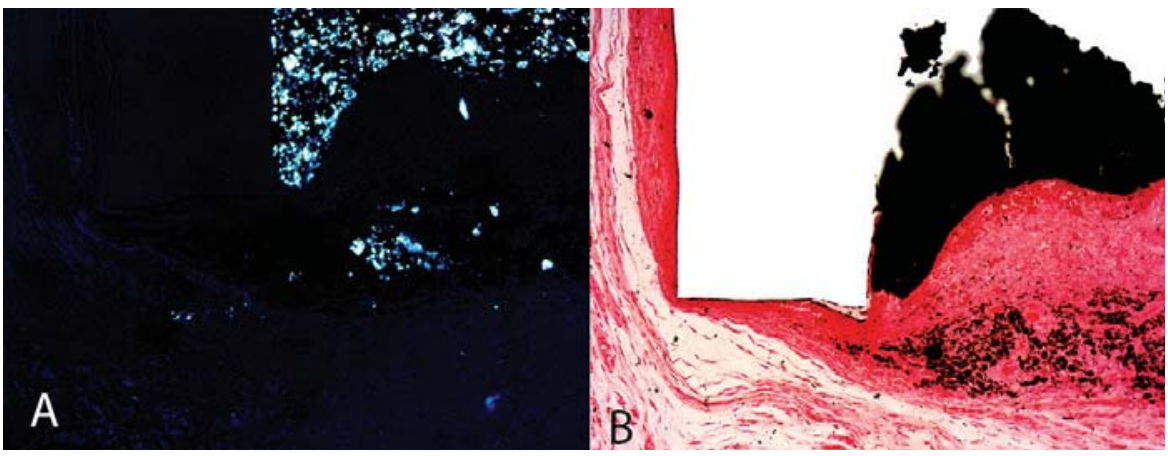

Figure 1- (A) Presence of dystrophic calcification on the tube opening; (B) Presence of birefringent structures exposed by polarized light; they have been formed by the reaction between the calcium ions derived from the material and the carbonic gas released from the tissues (Sealapex, 30 days, Von Kossa and polarized light; 10x) 
showing their biocompatible nature ${ }^{40}$.

Furthermore, even with the use of biocompatible sealers, which are capable of inducing mineralization, complete repair is only possible with the disinfection of the root canal system. Therefore, an improved repair process following RCT is promoted by the complete cleaning of the root canal, as well as by the use of an intracanal dressing, such as calcium hydroxide.

\section{Apical limit of obturation}

Systematic reviews have shown that root canal preparation and obturation inferior to the radiographic apex (root canal obturation at 1-2 mm inferior to the apex) were associated with a better prognosis (higher success rates) ${ }^{87}$.

Studies evaluating the success of endodontically treated teeth showed that overfills delayed the apical repair process $52,99,100$; the apical limit of obturation can affect the final outcome of endodontic treatment ${ }^{100}$. In addition, the findings observed in histological investigations corroborate these clinical and radiographic studies ${ }^{52}$ (Figure 2 and Figure 3 ).

Evidence has shown that the type of sealer applied can also affect the repair process. Suzuki, et al. ${ }^{99}$ (2011) investigated the effects of endomethasone as a filling material in canine teeth and found that none of the filling limits (inferior or above the apical foramen) promoted the complete repair of the periapical tissue. Furthermore, the presence of an intense inflammatory infiltrate was also observed in the cases of overfilling. Similar results were also obtained with EndoRez when evaluated as a filling material in canine teeth ${ }^{100}$, therefore corroborating the studies that showed high toxicity ${ }^{8}$ and the presence of moderate to severe inflammatory reactions in intraosseous implants ${ }^{96}$.

However, even the use of biocompatible materials, such as MTA, when used as filling beyond the limit of the apical foramen, showed unsatisfactory results ${ }^{52}$; this suggested that overfilling should be avoided.

\section{Expansion of the apical foramen}

Root canal cleaning with the use of flexible files is recommended for the endodontic treatment of necrotic teeth; additionally, the apical constriction is maintained. This procedure, which is also referred to as apical patency, is common; it prevents the compaction of dentin chips into the foramen and helps the local elimination of microorganisms that inhibit the process of repair following endodontic treatment. However, studies on canine teeth with periapical lesions showed that optimal results were obtained when the apical foramen was expanded to a greater extent than the patency instrument ${ }^{6}$.

The enlargement of the apical foramen affects the healing of chronic periapical lesions ${ }^{6}$. According to some authors, the compaction of debris into the apical third of the root canal should be removed mechanically ${ }^{106}$, while others believe that it can be removed with the use of abundant irrigation ${ }^{52}$, and that the infection could be additionally eliminated with the use of an intracanal dressing ${ }^{54}$. Moreover, the enlargement of the foramen appeared to hinder

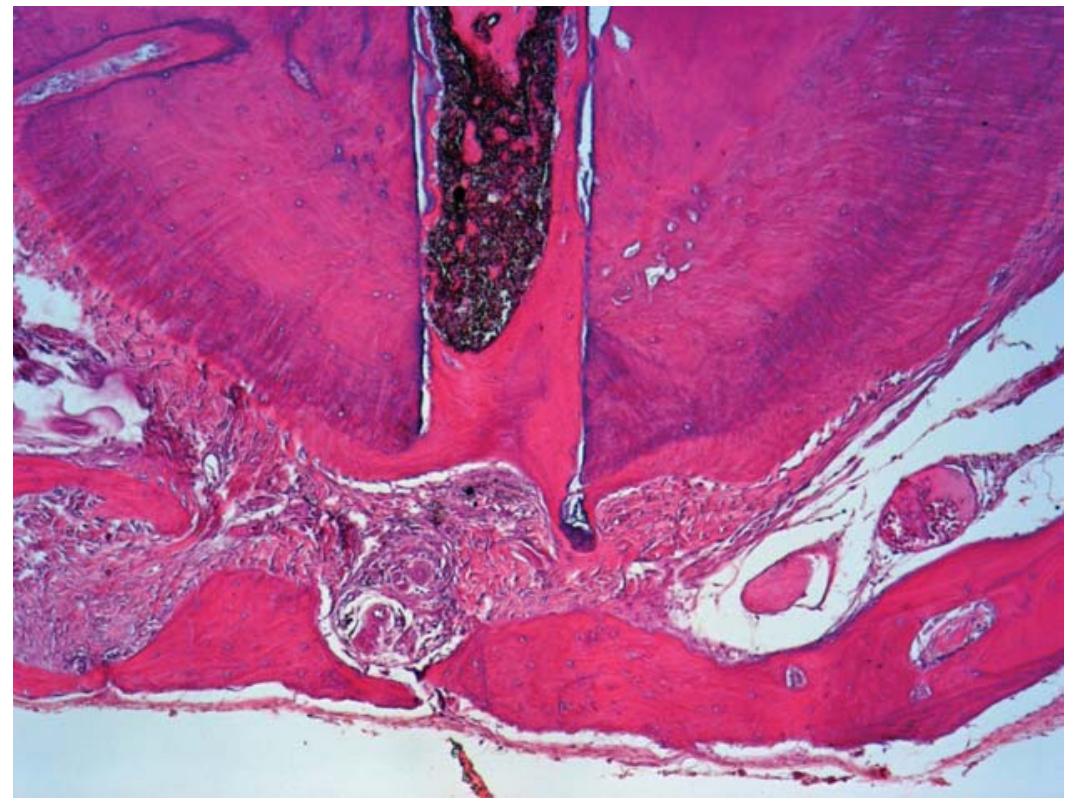

Figure 2- Process of obturation from the apical limit; a new cement sealing technique in the apical foramen, in close contact with Sealapex. Observe the normal organization of the periodontal ligament and alveolar bone close to the periapex $(\mathrm{HE}, 10 \times)$ 


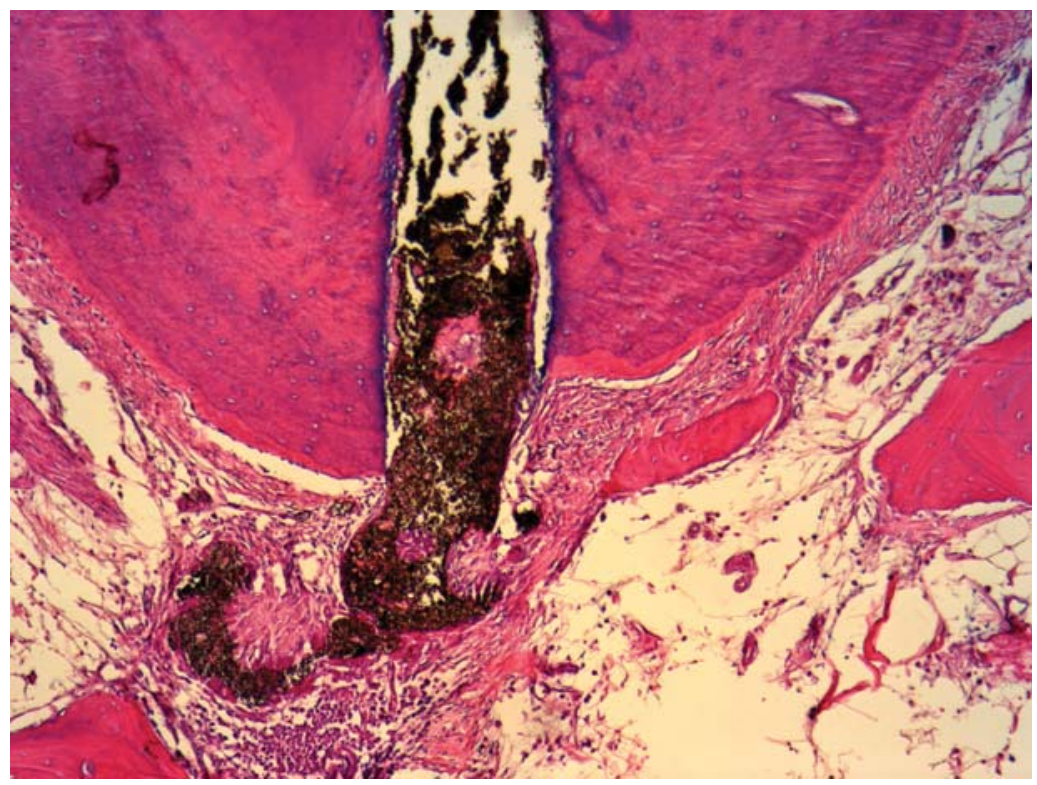

Figure 3- Obturation over the apical limit showing the absence of new cement sealing the apical foramen in close contact with Sealapex. Observe the partial disorganization of the periodontal ligament with the chronic inflammatory cells surrounding the extruded material and the alveolar bone distant from the periapex (HE, 10x)

the apical seal ${ }^{39}$

Apical patency is an important factor determining the success of endodontic treatment; nonetheless, further research concerning the enlargement of the foramen is required.

\section{Systemic factors that interfere in the repair process}

The repair of apical periodontitis in endodontically treated teeth depends on different therapeutic factors and clinical conditions ${ }^{19,65,89}$. Seltzer ${ }^{90}$ (1988) correlates the local and systemic factors affecting the endodontic repair process, and suggests that the failure of the endodontic treatment may be beyond the dentist's control. Local factors include: infection; hemorrhage, tissue injury; occlusion of the blood supply; and presence of foreign bodies. Systemic factors include: nutrition; stress; state of chronic debilitation; hormones; vitamin intake; dehydration; and age. Therewith, this review also aims to discuss the association between some systemic conditions, such as diabetes mellitus, hypertension, and osteoporosis, and the periapical healing process of endodontically treated teeth.

\section{Chronic conditions}

\section{Diabetes}

Diabetes mellitus (DM) is a metabolic disorder characterized by hyperglycemia resulting from a defect in the secretion of insulin and/or the impairment of its action ${ }^{3}$. Studies have been emphasizing the relationship between DM and oral diseases $29,48,65,89$. Fouad $^{25}$ (2003) showed that DM may be a modulating factor of endodontic infections, and that it may compromise the healing process of periapical tissues.

The association between periodontal disease and the incidence of DM has been reported in some studies $^{48}$; however, few studies have suggested that the incidence of DM was comorbid with endodontic disease. Cintra, et al. ${ }^{12}$ (2014) studied the influence of apical periodontitis and periodontal disease by examining the concentration of glycosylated hemoglobin ( $\mathrm{HbAlc}$ ) in normoglycemic and hyperglycemic rats. They observed that the incidence of endodontic infections that were either isolated or associated with periodontal disease had affected the glycemic control, especially in diabetic rats. This resulted in an increase in both blood glucose and $\mathrm{HbAlc}$ levels.

In another study ${ }^{14}$, the relationship between the blood profile and the histological findings of the cases involving apical periodontitis and periodontal disease associated with diabetes was examined. In the presence of oral infection, the authors observed an increase in the number of neutrophils, lymphocytes, and leukocytes, as well as significant statistical difference between the diabetics and the diabetics with endodontic and periodontal infection. Histological findings showed an exacerbation of inflammation, with the consequent increase in inflammatory cell infiltration and bone resorption in diabetic rats.

The relationship between endodontic infections and the interaction with systemic diseases is not 
clear. Hyperglycemia elevates the levels of systemic inflammatory markers ${ }^{48}$ and alters the various functions of the immune system ${ }^{91,102}$, including the release of inflammatory mediators. Cintra, et al. ${ }^{13}$ (2014) correlated the serum levels of interleukin-17 (IL-17) and the infiltration of neutrophils in the presence of apical periodontitis and/or periodontal disease in diabetic rats. They found that the comorbidity of both diseases increased the serum levels of IL-17 regardless of the diabetic condition. Furthermore, an increase in the neutrophil population was observed in diabetic rats.

Hyperglycemia resulting from DM promoted molecular and cellular effects that can predispose individuals to systemic complications, such as the dysfunction and failure of various organs ${ }^{3}$. Nephropathy is one of the chronic complications of DM, and a possible relationship to periodontal disease has been reported ${ }^{49}$.

Based on a previous study ${ }^{15}$, a relationship between the periapical lesions and/or the presence of periodontal disease and the serum creatinine levels in diabetes was also suggested. An increase in creatinine levels was observed in diabetic rats; the levels were elevated in the presence of oral infection. This suggested that a high glycemic increase may predispose individuals to renal disorders. An additional investigation was performed to evaluate the triglyceride and cholesterol levels in diabetic rats. The relationship between these factors and the incidence of pulpal and periodontal diseases was then examined; it was observed that the isolated cases of periodontal infection, or its association with endodontic infections, led to an increase in the triglyceride levels of diabetic rats. However, the difference in the cholesterol levels was not significant ${ }^{16}$.

Alterations in the health of the skeletal system were also associated with diabetes ${ }^{113}$. The control of inflammation is essential in the bone repair process ${ }^{4}$. Systemic inflammation, which is promoted by DM, can lead to a prolonged healing time in the case of fractures ${ }^{17}$. Previous studies ${ }^{38,41}$ evaluated the mineralization capacity and tissue response of MTA cement and two endodontic sealers, MTA Fillapex and Sealapex, using a diabetic model. The tissue response of these sealers was unaffected by the incidence of DM (Figure 4).

\section{Hypertension}

Hypertension is a chronic disorder that is characterized by an increased peripheral vascular resistance to blood flow. It is attributable to vascular remodeling, and elevates blood pressure in arteries ${ }^{111}$.

The relationship between hypertension and calcium loss in bones has been shown in clinical and experimental studies ${ }^{32,109}$. Likewise, the alteration in the activity and differentiation of bone cells observed in patients has been related to the incidence of hypertension ${ }^{60}$. It has been correlated with elevated blood pressure, incidence of dental problems (such as periodontal disease ${ }^{56,62}$ ), high rate of implant loss due to defects in the process of osseointegration ${ }^{2}$, and difficulties in bone healing following tooth extractions ${ }^{69}$.

Periodontal disease and chronic apical periodontitis showed similar inflammatory processes. Furthermore, patients with systemic diseases may have a reduced resistance to bacterial infection and tissue repair ${ }^{85}$.

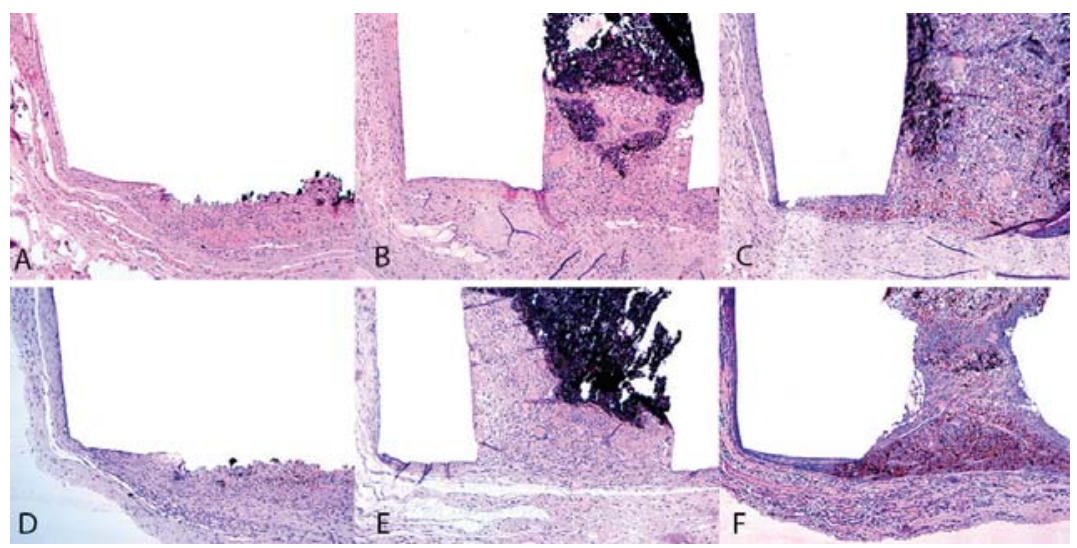

Figure 4- Tissue response of the subcutaneous tissue on the $30^{\text {th }}$ day under normal $(A, B, C)$ and diabetic (D, E, F) conditions. Use of Gray MTA Angelus ${ }^{\circledR}(A)$ and MTA Fillapex ${ }^{\circledR}(B)$ : in both materials, a mild inflammatory response with the infiltration of macrophages and lymphocytes was evident (hematoxylin-eosin, 10x magnification); Sealapex ${ }^{\circledR}(\mathrm{C})$ : thick, fibrous capsule formation and a moderate inflammatory cell infiltration (hematoxylin-eosin, 10× magnification); Gray MTA Angelus ${ }^{\circledR}$ (D): presence of a moderate inflammatory infiltration of macrophages and lymphocytes (hematoxylin-eosin, 10x magnification); MTA Fillapex ${ }^{\circledR}$ (E): presence of a mild inflammatory infiltration of macrophages and lymphocytes after 30 days (hematoxylin-eosin, 10× magnification); Sealapex ${ }^{\circledR}(\mathrm{F})$ : thick, fibrous capsule formation and moderate inflammatory cell infiltration (hematoxylin-eosin, 10× magnification) 
Periapical lesions occur as an inflammatory response to infection and, along with hypertension, can lead to vascular injury and inflammation ${ }^{70}$.

Martins, et al. ${ }^{70}$ (2016) evaluated the tissue response and mineralization capacity of MTA cement in hypertensive rats. The results showed that hypertensive rats had an intense inflammatory reaction and were characterized by a decreased mineralization rate compared to normotensive rats; this suggested that the comorbidity of hypertension was able to impair the tissue response and the mineralization ability of MTA.

The hypertensive state can be a risk factor for periodontitis and periapical lesions. However, further research linking hypertension and periapical lesion healing is required.

\section{Menopause/Osteoporosis}

The longer life expectancy of elderly individuals raises a concern for both the quality of life and the prevention of age-related diseases. In this context, an increase in the prevalence of bone fracture because of advanced age has been observed ${ }^{11}$, particularly in post-menopausal women; this is a result of the decreased concentration of estrogen.

Osteoporosis and apical periodontitis are two diseases that involve bone resorption. Studies have shown a significant correlation between these two diseases ${ }^{98,112}$. Xiong, et al. ${ }^{112}$ (2007) showed that the condition of apical periodontitis is aggravated by an estrogen deficiency. Low estrogen concentration also promoted an increase in the resorptive activity of the alveolar process in rats ${ }^{46,112}$.

Hormone replacement therapies (or the use of stabilizing substances for the process of resorption) aim to reduce the frequency of fractures and to prevent further loss of mature bone ${ }^{9}$. This includes the use of bisphosphonate ${ }^{9,28}$. Raloxifene, which is an example of bisphosphonate, is used in the treatment and prevention of osteoporosis in postmenopausal women ${ }^{27}$. Investigations using ovariectomized rats showed that this treatment also prevented bone loss and suppressed its formation. This resulted in reduced bone remodeling ${ }^{45,46}$

In addition, the relationship between the incidence of apical periodontitis in ovariectomized rats, with or without the treatment of Raloxifene, suggested that a deficiency in estrogen concentrations enhanced the progression of periapical lesions ${ }^{45,46}$

\section{Conclusion}

In summary, the repair process of endodontically treated teeth depends not only on the adoption of the correct clinical approaches to promote a better RCT (such as use of good irrigant solution, intracanal dressing, and root canal filling), but also on systemic factors (such as chronic diseases, hormones, and age) that can change the host's immune defenses and interfere in the outcome of root canal treatment and in the healing process.

\section{Acknowledgement}

The authors declare no conflicts of interest. This study was supported, in part, by the grants received from the National Council for Scientific and Technological Development (CNPq grants $n$. 301123/2013-6 to J.E.G.F., n. 305969/2015-3 to L.T.A.C., n. 306394/2011-1 to C.E.) and from the São Paulo Research Foundation (FAPESP grants $n$. 2012/06943-1, 2012/06785-7 and 2012/01153-2 to J.E.G.F., n. 2012/09987-0 and 2012/02083-8 to L.T.A.C.)

\section{References}

1- Adl A, Motamedifar M, Shams MS, Mirzaie A. Clinical investigation of the effect of calcium hydroxide intracanal dressing on bacterial lipopolysaccharide reduction from infected root canals. Aust Endod J . $2015 ; 41(1): 12-6$

2- Alsaadi G, Quirynen M, Komárek A, van Steenberghe D. Impact of local and systemic factors on the incidence of late oral implant loss. Clin Oral Implants Res. 2008; 19:670-6.

3- American Diabetes Association. Diagnosis and classification of diabetes mellitus. Diabetes Care. 2013;36(Suppl 1): S67-74.

4- Azar MR, Safi L, Nikaein A. Comparison of the cleaning capacity of Mtwo and Pro Taper rotary systems and manual instruments in primary teeth. Dent Res J (Isfahan). 2012;9(2): 146-51.

5- Berutti E, Chiandussi G, Paolino DS, Scotti N, Cantatore G, Castellucci $A$, et al. Canal shaping with WaveOne Primary reciprocating files and ProTaper system: a comparative study. J Endod. 2012; 38(4):505-9. 6- Borlina SC, Souza V, Holland R, Murata SS, Gomes-Filho JE, Dezan Junior $E$, et al. Influence of apical foramen widening and sealer on the healing of chronic periapical lesions induced in dogs' teeth. Oral Surg Oral Med Oral Pathol Oral Radiol Endod. 2010;109(6): 932-40.

7- Borsatto MC, Correa-Afonso AM, Lucisano MP, Bezerra da Silva RA, Paula-Silva FW, Nelson-Filho P, et al. One-session root canal treatment with antimicrobial photodynamic therapy (aPDT): an in vivo study. Int Endod J. 2016;49(6):511-8

8- Bouillaguet S, Wataha JC, Lockwood PE, Galgano C, Golay A, Krejci I. Cytotoxicity and sealing properties of four classes of endodontic sealers evaluated by succinic dehydrogenase activity and confocal laser scanning microscopy. Eur J Oral Sci. 2004; 112(2): 182-7. 
9- Cao Y, Mori S, Mashiba T, Westmore MS, Ma L, Sato M, et al. Raloxifene, estrogen, and alendronate affect the processes of fracture repair differently in ovariectomized rats. J Bone Miner Res. 2002; 17(12): 2237-46.

10- Childs DR, Murthy AS. Overview of wound healing and management. Surg Clin North Am. 2017;97(1): 189-207.

11- Christenson ES, Jiang X, Kagan R, Schnatz P. Osteoporosis management in post-menopausal women. Minerva Ginecol. 2012;64(3): 181-94.

12- Cintra LT, Facundo AC, Valentim D, Prieto AK, Silva CO, Sumida $\mathrm{DH}$, et al. Effect of oral infections on serum creatinine levels in diabetic rats. Int J Diabetol Vasc Dis Res. 2013;1:1-6.

13- Cintra LT, Samuel RO, Azuma MM, Ribeiro CP, Narciso LG, Lima VM, et al. Apical periodontitis and periodontal disease increase serum IL-17 levels in normoglycemic and diabetic rats. Clin Oral Investig. 2014; 18(9): 2123-8.

14- Cintra LT, Samuel RO, Facundo AC, Prieto AK, Sumida DH, Bomfim $S R$, et al. Relationships between oral infections and blood glucose concentrations or $\mathrm{HbAlc}$ levels in normal and diabetic rats. Int Endod J. $2014 ; 47(3): 228-37$.

15- Cintra LT, Silva Facundo AC, Azuma MM, Sumida DH, Astolphi RD, Bomfim SR, et al. Pulpal and periodontal diseases increase triglyceride levels in diabetic rats. Clin Oral Investig. 2013; 17(6): 1595-9.

16- Cintra LT, Silva Facundo AC, Prieto AK, Sumida DH, Narciso LG, Mogami Bomfim SR, et al. Blood profile and histology in oral infections associated with diabetes. J Endod. 2014;40(8):1139-44.

17- Claes L, Recknagel S, I gnatius A. Fracture healing under healthy and inflammatory conditions. Nat Rev Rheumatol. 2012;31:133-43.

18- Consolaro A. Inflamação e reparo: um sílabo para a compreensão clínica e implicações terapêuticas. Maringá: Dental Press; 2009.

19- Cotti E, Mercuro G. Apical periodontitis and cardiovascular diseases: previous findings and ongoing research. Int Endod J. 2015;48:926-32. 20- Estrela C, Bammann LL, Estrela CR, Silva RS, Pécora JD. Antimicrobial and chemical study of MTA, Portland cement, calcium hydroxide paste, Sealapex and Dycal. Braz Dent J. 2000; 11:3-9.

21- Estrela C, Estrela CR, Barbin EL, Spanó JC, Marchesan MA, Pécora JD. Mechanism of action of sodium hypochlorite. Braz Dent J. 2002; 13: 113-7.

22- Estrela C, Holland R, Estrela CR, Alencar AH, Sousa-Neto MD, Pécora JD. Characterization of successful root canal treatment. Braz Dent J. 2014; 25: 3-11.

23- Estrela C, Silva JA, Alencar AH, Leles CR, Decurcio DA. Efficacy of sodium hypochlorite and chlorhexidine on Enterococcus faecalis - a systematic review and meta-analysis. J Appl Oral Sci. 2008; 16:364-8. 24- Farhad A, Mohammadi Z. Calcium hydroxide: a review. Int Dent J. 2005; 55(5): 293-301.

25- Fouad AF. Diabetes mellitus as a modulating factor of endodontic infections. J Dent Educ. 2003;67:459-67.

26- Frough-Reyhani M, Ghasemi N, Soroush-Barhaghi M, Amini M, Gholizadeh Y. Antimicrobial efficacy of different concentration of sodium hypochlorite on the biofilm of Enterococcus faecalis at different stages of development. J Clin Exp Dent. 2016;8(5):e480-4.

27- Gambacciani M, Levancini M. Hormone replacement therapy and the prevention of postmenopausal osteoporosis. Prz Menopauzalny. 2014; 13(4): 213-20.

28- Gambacciani M, Levancini M. Management of postmenopausal osteoporosis and the prevention of fractures. Panminerva Med. 2014; 56(2): 115-31.

29- Garber SE, Shabahang S, Escher AP, Torabinejad M. The effect of hyperglycemia on pulpal healing in rats. J Endod. 2009; 35:60-2. 30- Garcez AS, Arantes-Neto JG, Sellera DP, Fregnani ER. Effects of antimicrobial photodynamic therapy and surgical endodontic treatment on the bacterial load reduction and periapical lesion healing. Three years follow up. Photodiagnosis Photodyn Ther. 2015; 12:575-80.
31- Gatewood RS. Endodontic materials. Dent Clin North Am. 2007;51(3):695-712.

32- Gealh WC, Pereira CC, Luvizuto ER, Garcia-J únior IR, Antoniali C, Okamoto R. Healing process of autogenous bone graft in spontaneously hypertensive rats treated with losartan: an immunohistochemical and histomorphometric study. J Oral Maxillofac Surg. 2014; 72(12):2569-81. 33- Georgopoulou M, Kontakiotis E, Nakou M. In vitro evaluation of the effectiveness of calcium hydroxide and paramonochlorophenol on anaerobic bacteria from the root canal. Endod Dent Traumatol. 1993; 9(6): 249-53.

34- Gill GS, Bhuyan AC, Kalita C, Das L, Kataki R, Bhuyan D. Single versus multi-visit endodontic treatment of teeth with apical periodontitis: an in vivo study with 1-year evaluation. Ann Med Health Sci Res. 2016;6(1): 19-26.

35- Giuliani V, Di Nasso L, Pace R, Pagavino G. Shaping ability of waveone primary reciprocating files and ProTaper system used in continuous and reciprocating motion. J Endod. 2014; 40: 1468-71.

36- Gomes BP, Endo MS, Martinho FC. Comparison of endotoxin levels found in primary and secondary endodontic infections. J Endod. 2012; 38(8): 1082-6

37- Gomes-Filho JE, Aurélio KG, Costa MM, Bernabé PF. Comparison of the biocompatibility of different root canal irrigants. J Appl Oral Sci. 2008; 16(2): 137-44

38- Gomes-Filho JE, Azevedo Queiroz IO, Watanabe S, Silva Santos LM, Lodi CS, Okamoto R, et al. Influence of diabetes mellitus on tissue response to MTA and its ability to stimulate mineralization. Dent Traumatol. 2015; 31:67-72.

39- Gomes-Filho JE, Hopp RN, Bernabé PF, Nery MJ, Otoboni Filho JA, Dezan Júnior E. Evaluation of the apical infiltration after root canal disruption and obturation. J Appl Oral Sci. 2008; 16:345-9.

40- Gomes-Filho JE, Moreira JV, Watanabe S, Lodi CS, Cintra LT, Dezan Júnior E, et al. Sealability of MTA and calcium hydroxide containing sealers. J Appl Oral Sci. 2012;20:347-51.

41- Gomes Filho JE, Queiroz ÍO, Watanabe S, Cintra LT, Ervolino E. Influence of diabetes mellitus on the mineralization ability of two endodontic materials. Braz Oral Res. 2016;30. pii: S180683242016000100218

42- Gomes-Filho JE, Watanabe S, Bernabé PF, Moraes Costa MT. A mineral trioxide aggregate sealer stimulated mineralization. J Endod. 2009; 35(2):256-60

43- Gomes-Filho JE, Watanabe S, Cintra LT, Nery MJ, Dezan-Júnior E, Queiroz IO, et al. Effect of MTA-based sealer on the healing of periapical lesions. J Appl Oral Sci. 2013;21:235-42.

44- Gomes-Filho JE, Watanabe S, Lodi CS, Cintra LT, Nery MJ, Filho JA, et al. Rat tissue reaction to MTA FILLAPEX. Dent Traumatol. 2012; 28(6): 452-6.

45- Gomes-Filho JE, Wayama MT, Dornelles RC, Ervolino E, Coclete GA, Duarte PC, et al. Effect of raloxifene on periapical lesions in ovariectomized rats. J Endod. 2015;41:671-5.

46- Gomes-Filho JE, Wayama MT, Dornelles RC, Ervolino E, Yamanari GH, Lodi CS, et al. Raloxifene modulates regulators of osteoclastogenesis and angiogenesis in an oestrogen deficiency periapical lesion model. Int Endod J. 2015; 48(11): 1059-68.

47- Gorduysus M, Nagas E, Torun OY, Gorduysus O. A comparison of three rotary systems and hand instrumentation technique for the elimination of Enterococcus faecalis from the root canal. Aust Endod J. $2011 ; 37(3): 128-33$.

48- Graves DT, Liu R, Oates TW. Diabetes-enhanced inflammation and apoptosis: impact on periodontal pathosis. Periodontol 2000. 2007; 45: 128-37.

49- Grubbs V, Plantinga LC, Crews DC, Bibbins-Domingo K, Saran R, Heung $M$, et al. Vulnerable populations and the association between periodontal and chronic kidney disease. Clin J Am Soc Nephrol. 2011;6: 711-7. 
50- Guida A. Mechanism of action of sodium hypochlorite and its effects on dentin. Minerva Stomatol. 2006;55(9):471-82.

51- Hauman $\mathrm{CH}$, Love RM. Biocompatibility of dental materials used in contemporary endodontic therapy: a review. Part 1. Intracanal drugs and substances. Int Endod J. 2003;36(2):75-85.

52- Holland R, Mazuqueli L, Souza V, Murata SS, Dezan J únior E, Suzuki P. Influence of the type of vehicle and limit of obturation on apical and periapical tissue response in dogs' teeth after root canal filling with mineral trioxide aggregate. J Endod. 2007:33:693-7.

53- Holland R, Murata SS, Barbosa HG, Garlipp O, Souza V, Dezan J unior E. Apical seal of root canals with gutta-percha points with calcium hydroxide. Braz Dent J. 2004; 15:26-9.

54- Holland R, Otoboni Filho JA, Souza V, Nery MJ, Bernabé PF, Dezan E J r. A comparison of one versus two appointment endodontic therapy in dogs' teeth with apical periodontitis. J Endod. 2003; 29:121-4.

55- Holland R, Souza V, Nery MJ, Otoboni Filho JA, Bernabé PF, Dezan Júnior $\mathrm{E}$. Reaction of rat connective tissue to implanted dentin tubes filled with mineral trioxide aggregate or calcium hydroxide. J Endod. 1999; 25: 161-6.

56- Holmlund A, Holm G, Lind L. Severity of periodontal disease and number of remaining teeth are related to the prevalence of myocardial infarction and hypertension in a study based on 4,254 subjects. J Periodontol. 2006; 77: 1173-8.

57- Jitaru S, Hodisan I, Timis L, Lucian A, Bud M. The use of bioceramics in endodontics - literature review. Clujul Med. 2016;89(4):470-3. 58- Küçükyilmaz E, Savas S, Saygili G, Uysal B. Assessment of apically extruded debris and irrigant produced by different nickel-titanium instrument systems. Braz Oral Res. 2015;29:1-6.

59- Kumar P, Prasad N, Darawade A, Bhagat SK, Narayana N, Darawade $P$. The effect of four commonly used root canal irrigants on the removal of smear layer: an in-vitro scanning electron microscope study. J Int Oral Health. 2015; 7(9):88-93.

60- Landim de Barros T, Brito V, Amaral CC, Chaves-Neto AH, Campanelli AP, Oliveira SH. Osteogenic markers are reduced in bonemarrow mesenchymal cells and femoral bone of young spontaneously hypertensive rats. Life Sci. 2016; 146: 174-83.

61- Lee MT, Bird PS, Walsh LJ. Photo-activated disinfection of the root canal: a new role for lasers in endodontics. Aust Endod J. 2004; 30(3): 93-8.

62- Leite CL, Redins CA, Vasquez EC, Meyrelles SS. Experimentalinduced periodontitis is exacerbated in spontaneously hypertensive rats. Clin Exp Hypertens. 2005; 27(6):523-31.

63- Leonardo MR, Hernandez ME, Silva LA, Tanomaru-Filho M. Effect of a calcium hydroxide-based root canal dressing on periapical repair in dogs: a histological study. Oral Surg Oral Med Oral Pathol Oral Radiol Endod. 2006; 102(5):680-5.

64- Leonardo MR, Salgado AA, Silva LA, Tanomaru Filho M. Apical and periapical repair of dogs' teeth with periapical lesions after endodontic treatment with different root canal sealers. Pesqui Odontol Bras. 2003; 17(1):69-74.

65- Lima SM, Grisi DC, Kogawa EM, Franco OL, Peixoto VC, GonçalvesJúnior JF, et al. Diabetes mellitus and inflammatory pulpal and periapical disease: a review. Int Endod J. 2013;46(8):700-9.

66- Loi F, Córdova LA, Pajarinen J, Lin TH, Yao Z, Goodman SB. Inflammation, fracture and bone repair. Bone. 2016;86:119-30.

67- López-J iménez L, Fusté E, Martínez-Garriga B, Arnabat-Domínguez J, Vinuesa T, Viñas M. Effects of photodynamic therapy on Enterococcus faecalis biofilms. Lasers Med Sci. 2015;30(5):1519-26.

68- Manfredi M, Figini L, Gagliani M, Lodi G. Single versus multiple visits for endodontic treatment of permanent teeth. Cochrane Database Syst Rev. 2016; 12: CD005296.

69- Manrique N, Pereira CC, Garcia LM, Micaroni S, Carvalho AA, Perri $\mathrm{SH}$, et al. Alveolar bone healing process in spontaneously hypertensive rats (SHR). A radiographic densitometry study. J Appl Oral Sci. $2012 ; 20(2): 222-7$
70- Martins CM, Gomes-Filho JE, Azevedo Queiroz IO, Ervolino E, Cintra LT. Hypertension undermines mineralization-inducing capacity of and tissue response to mineral trioxide aggregate endodontic cement. J Endod. 2016; 42(4):604-9.

71- Mizuno M, Banzai Y. Calcium ion release from calcium hydroxide stimulated fibronectin gene expression in dental pulp cells and the differentiation of dental pulp cells to mineralized tissue forming cells by fibronectin. Int Endod J. 2008;41(11):933-8.

72- Nair PN, Henry S, Cano V, Vera J. Microbial status of apical root canal system of human mandibular first molars with primary apical periodontitis after "one-visit" endodontic treatment. Oral Surg Oral Med Oral Pathol Oral Radiol Endod. 2005; 99:231-52.

73- Nery MJ, Gomes-Filho JE, Holland R, Souza V, Bernabé, PF, Otoboni Filho JA, et al. Influência do hipoclorito de sódio no processo de reparo de dentes de cães tratados em sessão única. Dent Press Endod. 2011; 1:21-7.

74- Oliveira LD, Jorge AO, Carvalho CA, Koga-Ito CY, Valera MC. In vitro effects of endodontic irrigants on endotoxins in root canals. Oral Surg Oral Med Oral Pathol Oral Radiol Endod. 2007; 104(1): 135-42.

75- Panitvisai P, Parunnit P, Sathorn C, Messer HH. Impact of a retained instrument on treatment outcome: a systematic review and metaanalysis. J Endod. 2010; 36(5): 775-80.

76- Parashos $\mathrm{P}$, Messer $\mathrm{HH}$. Rotary NiTi instrument fracture and its consequences. J Endod. 2006; 32(11): 1031-43.

77- Paredes-Vieyra J, Enriquez FJ. Success rate of single- versus two-visit root canal treatment of teeth with apical periodontitis: a randomized controlled trial. J Endod. 2012; 38(9): 1164-9.

78- Patil AA, J oshi SB, Bhagwat SV, Patil SA. Incidence of postoperative pain after single visit and two visit root canal therapy: a randomized controlled trial. J Clin Diagn Res. 2016; 10(5): ZC09-12.

79- Peters OA. Current challenges and concepts in the preparation of root canal systems: a review. J Endod. 2004;30:559-67.

80- Pinheiro SL, Araujo G, Bincelli I, Cunha R, Bueno C. Evaluation of cleaning capacity and instrumentation time of manual, hybrid and rotary instrumentation techniques in primary molars. Int Endod J. 2012; 45(4): 379-85

81- Prashanth MB, Tavane PN, Abraham S, Chacko L. Comparative evaluation of pain, tenderness and swelling followed by radiographic evaluation of periapical changes at various intervals of time following single and multiple visit endodontic therapy: an in vivo study. J Contemp Dent Pract. 2011;12(3): 187-91.

82- Prichard J. Rotation or reciprocation: a contemporary look at NiTi instruments? Br Dent J. 2012;212(7):345-6.

83- Rôças IN, Lima KC, Siqueira J F J r. Reduction in bacterial counts in infected root canals after rotary or hand nickel-titanium instrumentation - a clinical study. Int Endod J. 2013;46(7):681-7.

84- Rodrigues CT, Duarte MA, Almeida MM, Andrade FB, Bernardineli $\mathrm{N}$. Efficacy of $\mathrm{CM}$-wire, M-wire, and nickel-titanium instruments for removing filling material from curved root canals: a micro-computed tomography study. J Endod. 2016;42: 1651-5.

85- Sasaki H, Hirai K, Martins CM, Furusho H, Battaglino R, Hashimoto K. Interrelationship between periapical lesion and systemic metabolic disorders. Curr Pharm Des. 2016;22: 2204-15.

86- Saxena P, Gupta SK, Newaskar V. Biocompatibility of root-end filling materials: recent update. Restor Dent Endod. 2013;38(3): 119-27. 87- Schaeffer MA, White RR, Walton RE. Determining the optimal obturation length: a meta-analysis of literature. J Endod. 2005; 31:2714.

88- Schäfer E, Lohmann D. Efficiency of rotary nickel-titanium FlexMaster instruments compared with stainless steel hand K-Flexofile - Part 1. Shaping ability in simulated curved canals. Int Endod J 2002; 35:505-13.

89- Segura-Egea JJ, Martín-González J, Castellanos-Cosano L. Endodontic medicine: connections between apical periodontitis and systemic diseases. Int Endod J. 2015;48:933-51. 
90- Seltzer S. Repair following root canal therapy. In: Endodontology: biologic considerations in endodontic procedures. Philadelphia: Lea Fabinger; 1988. p. 389-438.

91- Shetty N, Thomas B, Ramesh A. Comparison of neutrophil functions in diabetic and healthy subjects with chronic generalized periodontitis. J Indian Soc Periodontol. 2008; 12(2):41-4.

92- Shrestha A, Cordova M, Kishen A. Photoactivated polycationic bioactive chitosan nanoparticles inactivate bacterial endotoxins. J Endod. 2015; 41:686-91.

93- Silva EJ, Orlowsky NB, Herrera DR, Machado R, Krebs RL, CoutinhoFilho TS. Effectiveness of rotatory and reciprocating movements in root canal filling material removal. Braz Oral Res. 2015;29:1-6.

94- Singh A, Arunagiri D, Pushpa S, Sawhny A, Misra A, Khetan K. Apical extrusion of debris and irrigants using ProTaper hand, M-two rotary and WaveOne single file reciprocating system: an ex vivo study. J Conserv Dent. 2015; 18(5):405-8.

95- Siqueira JF J r, Rôças IN, Favieri A, Lima KC. Chemomechanical reduction of the bacterial population in the root canal after instrumentation and irrigation with $1 \%, 2.5 \%$, and $5.25 \%$ sodium hypochlorite. J Endod. 2000;26:331-4.

96- Sousa CJ, Montes CR, Pascon EA, Loyola AM, Versiani MA. Comparison of the intraosseous biocompatibility of AH Plus, EndoREZ, and Epiphany root canal sealers. J Endod. 2006; 32:656-62.

97- Subramaniam P, Tabrez TA, Babu KL. Microbiological assessment of root canals following use of rotary and manual instruments in primary molars. J Clin Pediatr Dent. 2013;38:123-7.

98- Sultan N, Rao J. Association between periodontal disease and bone mineral density in postmenopausal women: a cross sectional study. Med Oral Patol Oral Cir Bucal. 2011; 16: e440-7.

99- Suzuki P, Souza Vd, Holland R, Gomes-Filho JE, Murata SS, Dezan Junior $E$, et al. Tissue reaction to Endométhasone sealer in root canal fillings short of or beyond the apical foramen. J Appl Oral Sci. 2011; 19:511-6.

100- Suzuki P, Souza V, Holland R, Murata SS, Gomes-Filho JE, Dezan Junior $E$, et al. Tissue reaction of the EndoREZ in root canal fillings short of or beyond an apical foramenlike communication. Oral Surg Oral Med Oral Pathol Oral Radiol Endod. 2010; 109: e94-9.

101- Tanomaru J M, Tanomaru-Filho M, Hotta J, Watanabe E, I to IY. Antimicrobial activity of endodontic sealers based on calcium hydroxide and MTA. Acta Odontol Latinoam. 2008;21:147-51.

102- Tard C, Rouxel O, Lehuen A. Regulatory role of natural killer T cells in diabetes. Biomed J. 2015;38(6):484-95.

103- Tartari T, Guimarães BM, Amoras LS, Duarte MA, Silva e Souza PA, Bramante CM. Etidronate causes minimal changes in the ability of sodium hypochlorite to dissolve organic matter. Int Endod J. 2015; 48(4): 399-404.
104- Teixeira CS, Felippe MC, Felippe WT. The effect of application time of EDTA and $\mathrm{NaOCl}$ on intracanal smear layer removal: an SEM analysis. Int Endod J. 2005; 38(5): 285-90.

105- Tewari RK, Ali S, Mishra SK, Kumar A, Andrabi SM, Zoya A, et al. Mechanical reduction of the intracanal Enterococcus faecalis population by Hyflex CM, K3XF, ProTaper Next, and two manual instrument systems: an in vitro comparative study. J Investig Clin Dent. 2016; 7(2): 168-73.

106- Tinaz AC, Alacam T, Uzun O, Maden M, Kayaoglu G. The effect of disruption of apical constriction on periapical extrusion. J Endod. 2005; 31:533-5.

107- Tinoco JM, De-Deus G, Tinoco EM, Saavedra F, Fidel RA, Sassone LM. Apical extrusion of bacteria when using reciprocating single-file and rotary multifile instrumentation systems. Int Endod $\mathrm{J}$. 2014; 47(6): 560-6.

108- Trindade AC, Figueiredo JA, Steier L, Weber JB. Photodynamic therapy in endodontics: a literature review. Photomed Laser Surg. 2015; 33: 175-82.

109- Tsuda K, Nishio I, Masuyama Y. Bone mineral density in women with essential hypertension. Am J Hypertens. 2001; 14(7 Pt 1): 704-7. 110- Vaziri S, Kangarlou A, Shahbazi R, Nazari Nasab A, Naseri M. Comparison of the bactericidal efficacy of photodynamic therapy, $2.5 \%$ sodium hypochlorite, and $2 \%$ chlorhexidine against Enterococcous faecalis in root canals; an in vitro study. Dent Res J (Isfahan). 2012;9(5):613-8.

111- World Health Organization - WHO. A global brief on hypertension: silent killer, global public health crisis. Geneva: World Health Organization; 2013.

112- Xiong H, Peng B, Wei L, Zhang X, Wang L. Effect of an estrogendeficient state and alendronate therapy on bone loss resulting from experimental periapical lesions in rats. J Endod. 2007; 33(11): 1304-8. 113- Yaturu S. Diabetes and skeletal health. J Diabetes. 2009; 1(4):24654.

114- Yildirim C, Karaarslan ES, Ozsevik S, Zer Y, Sari T, Usumez A. Antimicrobial efficiency of photodynamic therapy with different irradiation durations. Eur J Dent. 2013;7(4):469-73.

115- Zand V, Milani AS, Amini M, Barhaghi MH, Lotfi M, Rikhtegaran $S$, et al. Antimicrobial efficacy of photodynamic therapy and sodium hypochlorite on monoculture biofilms of Enterococcus faecalis at different stages of development. Photomed Laser Surg. 2014; 32(5): 245-51. 